\title{
KEMEROSOTAN NILAI MORAL YANG TERJADI PADA GENERASI MUDA DI ERA MODERN
}

\section{Indriana Wijayanti}

\author{
Program Studi Pendidikan IPS Universitas Lambung Mangkurat \\ Email : indrianawijayanti2@gmail.com
}

\begin{abstract}
Abstrak
Era modern merupakan era dimana marak sekali yang namanya perkembangan, baik itu perkembangan kebudayaan, perkembangan pendidikan maupun teknologi. Namun tentunya, era modern tak selamanya berdampak baik bagi kehidupan. Di era global sekarang, banyak sekali terjadi permasalahan moral pada generasi muda yang sudah tidak sesuai dengan norma dan melewati batas. Akan sangat di sayangkan apabila adanya era global ini membuat generasi mudanya tidak memiliki nilai moral dalam dirinya. Adapun metode penulisan dalam artikel ini, yaitu metode literatur dengan mengumpulkan berbagai sumber bacaan dari artikel dan jurnal yang kemudian di analisis dan kemudian menghubungkanya dengan permasalahan yang di bahas. Berdasarkan hasil analisis yang di telah di lakukan, adapun hasil yang kemudian di bahas dalam artikel ini yaitu, yang pertama tentang nilai moral, kedua tentang fenomena kemerosotan moral pada remaja yang di sebabkan oleh adanya perkembangan zaman dan adanya globalisasi, ketiga pentingnya penananman nilai moral pada anak yang di lakukan melalui jalur pendidikan.
\end{abstract}

Kata Kunci : kemerosotan moral, nilai-nilai moral, pendidikan moral 


\section{PENDAHULUAN}

Era modern merupakan era dimana marak sekali yang namanya perkembangan, baik itu perkembangan kebudayaan, perkembangan pendidikan maupun teknologi. Hal yang sangat biasa ketika banyak orang sekarang lebih nyaman dengan menggunakan teknologi. Perkembangan-perkembangan tersebut tentunya memberikan kemudahan dan tentunya memberikan dampak positif bagi masyarakatnya. Tidak dipungkiri bahwa adanya era globalisasi ini merubah seluruh kehidupan di masyarakat, baik itu adat, budaya, sistem sosial politik dan lain-lain yang mempengaruhi setiap elemen kehidupan (Mutiani, 2018). di era modern ini juga menimbulkan dampak negatif, seperti kemerosotan nilai-nilai moral dan sikap sosial yang mulai memudar.

Sangat di sayangkan apabila nilai-nilai moral dan sosial tersebut luntur di dalam kehidupan masyarakat. mereka akan menjadi orang-orang yang tidak peduli dan masa bodo dengan sekitar. Hal inilah yang sedang dirasakan oleh masyarakat terutama para generasi-generasi muda dimana sebagian dari mereka nilai kepekaan sosialnya sangat kurang. Hal inilah yang menjadi permasalahan sekarang, dimana seharusnya semakin maju perkembangan zaman namun masyarakatnya malah tidak memiliki moral yang baik seperti yang diajarkan sejak dahulu kala. Untuk itulah penting untuk menanamkan nilainilai moral pada anak yang sekarang ini telah luntur agar mereka menjadi generasi yang berkualitas dimasa depan nantinya yaitu dengan jalur pendidikan di sekolah (Aini dkk, 2016).

\section{METODE PENULISAN}

Metode yang digunakan dalam penulisan ini ialah dengan menggunakan metode literatur, yaitu dengan cara mengumpulkan berbagai bahan bacaan dari berbagai sumber yang ada yang kemudian dianalisis dan menghubungkanya dengan permasalahan yang dibahas.

\section{PEMBAHASAN}

\section{Nilai Moral}

Menurut Suseno dalam (Ananda 2017), nilai moral merupakan sebuah ukuran dari sikap dan perilaku seseorang, entah itu diukur dari sikap baik ataupun buruk dan benar maupun salah. Orang akan dikatakan bermoral apabila ia dalam berperilaku memiliki etika yang baik dan tidak melanggar norma yang berlaku di masyarakat. karena pada dasarnya moral sama maknanya dengan kesusilaan, bagaimana kita bertingkah laku 
diukur dari bagaimana kita bersikap di dalam suatu lingkungan dengan menjunjung tinggi nilai-nilai kesusilaan sesuai dengan aturan dan norama yang ada. Berperilaku tentu saja tidak boleh semena-mena dan sembarangan, harus ada ukuran dalam setiap sikap yang kita jalankan karena pada dasarnya moral dikatakan sebagai sebuah patokan seseorang dalam berperilaku di masyarakat (Subiyakto\&Mutiani 2019). Artinya setiap manusia memiliki aturan-aturan dan ukuran dalam berperilaku dan bersikap, baik dalam ruang lingkup keluarga dan ruang lingkup masyarakat.

Bayangkan saja apabila perilaku tidak di dasari dengan adanya aturan yang ada, maka yang akan terjadi ialah banyaknya kasus pelanggaran norma dan kejahatan yang tidak memiliki nilai moral sama sekali. Karena pada dasarnya mereka telah melewati batasan dalam bertindak yang menyebabkan penyimpangan perilaku terjadi. Adanya moral akan membuat masyarakat berperilkau sesuai dengan aturan dan kaidah yang ada. Orang akan di senangi ketika mereka bertingkah laku sesuai dengan batas dan bertingkah laku dengan santun dan baik. tanpa adanya moral di dalam sebuah kehidupan akan membuat berbagai permasalahan-permasalahan sosial yang terjadi di masyarakat. menurut Hidayat (2011) dalam (Syaharuddin, 2016) Untuk membangun masyarakat yang tertib dan damai serta sejahtera maka perlu di tanamkan nilai moral pada anak, karena moral merupakan faktor utama untuk membentuk masyarakat yang sejahtera.

\section{Fenomena kemerosotan moral pada generasi muda}

Di era modern ini marak sekali dengan perubahan dan juga perkembangan yang terjadi di kehidupan masyarakat. Hal tersebut bukan hanya terjadi pada Indonesia saja, namun terjadi di seluruh dunia. Adanya globalisasi membuat banyaknya perubahan itu terjadi, baik itu dari ekonomi, politik, sosial maupun budaya. Adaya perubahan yang di akibatkan oleh globalisasi ini sendiri di pengaruhi karena adanya ilmu pengetahuan dan juga kemajuan teknologi yang menciptakan keragaman budaya di dunia yang bersifat homogen.

Banyak sekali fenomena permasalahan sosial yang sering terjadi dalam kehidupan masyarakat saat ini di era modern karena adanya globalisasi. contohnya saja seperti fenomena kemerosotan moral yang terjadi pada generasi muda. Kemerosotan moral itu di tandai dengan adanya berbagai pelanggaran dan tindakaan kejahatan yang ada di masyarakat, seperti pencurian, perkataan kasar, hilangnya rasa hormat kepada yang lebih 
tua dan lain sebagainya, adanya perilaku negatif tadi merupakan sebuah tanda akan hancurnya sebuah bangsa (Syaharuddin 2016 ).

Jika diperhatikan dengan seksama, moralitas yang ada pada manusia terutama yang ada pada generasi muda sekarang sudah mulai luntur, banyak sekali anak-anak zaman sekarang yang berperilaku tanpa moral di dalamnya. Karena pada dasarnya generasi muda merupakan generasi yang mudah terpengaruh dan rentan dengan adanya pergeseran moral (Bahri, 2015) Hal ini sering kita lihat dalam kehidupan nyata dimana mereka sudah berperilaku melewati batasan, dimana mereka tidak lagi memiliki kebijaksanaan dalam berperilaku, hal itu sangat menghawatirkan untuk kondisi sekarang. Karena tanpa moralitas yang tertanam pada diri seseorang, maka rusak sudah bangsa ini nantinya.

Banyak berbagai faktor-faktor yang memperngaruhi terjadinya kemerosotan moral yang ada pada diri anak remaja sekarang. Satu diantara faktor yang memperngaruhinya ialah adanya globalisasi, dimana adanya globalisasi membuat banyak sekali perubahan dalam kehidupan masyarakat di dalamnya, masuknya berbagai ideologi, teknologi bahkan kebudayaan dapat merubah tatanan kehidupan dalam masyarakatnya (Mutiani 2018).

Kebudayaan modern yang masuk dari luar ke dalam negri dapat mempengaruhi segala tingkah laku dari orang yang menerima adanya perubahan itu. karena pada dasarnya masuknya segala hal melalui globalisasi akan merubah segala hal baik itu udari tatanan kehidupan maupun perilaku di kehidupan masyarakat. sebab masyarakat sepenuhnya belum bisa untuk menyaring berbagai perubahan yang terjadi secara cepat, akibatnya masyarakat banyak yang tidak siap hingga mereka tidak dapat memfilter bagian mana dari globalisasi yang akan memberikan dampak positif maupun negatif kepada mereka. Perubahan itu juga menimbulkan krisis moral pada anak remaja yang menerimanya, karena mereka belum memahami secara utuh tentang dampak yang di timbulkan dari adanya globalisasi ini.

Lunturnya moral pada remaja juga bisa diakibatkan karena mereka melupakan dan bahkan tidak mengetahui kebudayaan di daerah mereka sendiri, hal itu juga dapat terlihat dari maraknya para remaja yang mengikuti perilaku maupun kebudayaan yang berasal dari luar, dimana hal itu banyak nya tidak memberikan dampak positif kepada mereka. Remaja tidak mengetahui dan bahkan tidak mencintai kebudayaan mereka 
sendiri yang sudah ada sejak luhur dimana kebudayaan lokal tersebut memiliki nilai-nilai kebijaksanaan di dalamnya (Bahri, 2015).

Banyak sekali fenomena yang menunjukkan bahwasanya para generasi mudah di era sekarang ini (era modern) tidak memiliki moral dalam dirinya, dimana hal itu mereka dapatkan dari hasil meniru kebiasaan dan kebudayaan dari luar yang tidak baik dan menyimpang melalui internet dan media sosial yang tidak bisa di cegah. Teknologi seperti halnya smartphone memang memberikan berbagai kemudahan di dalam kehidupan, namun tidak dapat di pungkiri bahwa teknologi akan memberikan dampak buruk apabila penggunanya tidak memakainya secara bijaksana. Akibatnya luntur sudah moralitas, rasa tanggung jawab dan rasa hormat kepada orang lain yang lebih tua di bandingkan dengan mereka bahkan nilai kebudayaan luhur sudah sangat minim di temui pada diri remaja.

Sangat di sayangkan apabila remaja sekarang nilai kebudayaan nya mulai luntur seiring dengan lunturnya nilai moralitas yang juga ada pada dirinya diakibatkan oleh adanya perubahan karena globalisasi. Karena pada dasarnya kebudayaan lokal memiliki banyak nilai kebaikan dan kearifan di dalamnya, dimana jika remaja memiliki nilai tersebut di dalam dirinya maka akan pula tertanam nilai-nilai moral dan norma-norma pada dirinya.

\section{Pentingnya Penanaman nilai moral pada anak}

Moral tidak serta merta ada secara alamiah dalam diri setiap manusia ketika mereka dilahirkan. Penanaman nilai moral sangat penting dilakukan, terutama kepada anak sejak dini, hal itu di lakukan agar mereka terbiasa untuk dapat berperilaku sesuai dengan aturan dan juga sesuai dengan kaidah-kaidah yang ada di dalam masyarakat itu sendiri. Penanaman nilai moral bisa dilakukan lewat pendidikan, baik itu secara formal seperti sekolah ataupun dengan pendidikan secara non formal, seperti lingkungan keluarga dan masyarakat. ketiganya sama-sama memiliki peranan yang penting untuk proses penanaman moral pada anak. Lingkungan yang memiliki peran yang paling penting tentu saja lingkungan keluarga. Sebab lingkungan keluarga merupakan lingkungan pertama kali di mana anak akan didik segala tingkah laku dan moralnya (Fahrudin, 2014).

Lingkungan keluarga memiliki kewajiban dalam mendidik nilai-nilai kebaikan pada anak agar mereka menjadi individu yang baik ketika mereka berada di masyarakat. Dalam lingkungan keluarga anak akan menemukan unsur-unsur dari setiap 
kepribadianya, mulai dari tanggung jawab, pembentukan sikap menghormati dan kontrol emosional akan terbentuk ketika anak dididik sejak dini oleh keluarganya. Dalam hal ini keluarga tidak hanya penting bagi seorang anak, namun juga presensinya sangat penting di masyarakat, sebab lingkungan keluarga yang baik dan sehat akan memberikan sebuah kualitas tingkah laku anggotanya di masyarakat kelak, sebab keluarga unit terkecil dari masyarakat yang memiliki peran penting untuk anggota keluarganya. (Fahrudin, 2014).

\section{Penanaman nilai moral di sekolah}

Peran guru tentunya sangat penting dalam pembelajaran, sebab guru tidak hanya di tuntut untuk menyampaikan sebuah materi kepada siswanya saja, namun dalam hal untuk memperbaiki karakter peserta didik tentunya guru punya peran yang besar disini. Guru harus memiliki strategi dalam sebuah pembelajaran untuk membuat nilai-nilai yang dia ajarkan ke siswa tidak hanya di pahami secara teoritis, namun bagaimana agar nilai tersebut dapat di jadikan sebuah pedoman dalam kehiduapan bagi peserta didik dalam lingkungan sekitar. (Subiyakto dan Abbas, 2020 ).

Penanaman nilai moral melalui jalur pendidikan, dapat di lakukan dengan berbagai cara oleh guru. Satu diantara nya yaitu dengan menggunakan kearifan lokal sebagai sumber belajar peserta didik. Sebab kearifan lokal sendiri merupakan sebuah identitas dan jati diri dari bangsa itu sendiri (Susanto, 2019 ). Dalam kearifan lokal terdapat sebuah kebijaksanaan dan nilai-nilai yang mencakup, nilai sosial, etika ekonomi, nilai moral dan etos budaya. Apabila nilai kearifan lokal di implikasikan dalam kehidupan sehari-hari oleh peserta didik maka akan terbentuk pula sebuah nilai moral pada diri mereka sendiri.

Selain dengan menggunakan kebudayaan lokal, penanaman moral juga dapat di lakukan dengan cara membiasakan muridnya. Pembiasaan ini sendiri tentunya harus di lakukan oleh guru semenjak anak duduk di bangku SD sampai ke sekolah menengah. Pembiasaan itu sendiri seperti pembiasaan perilaku untuk jujur, jalan menunduk ketika ada orang yang lebih tua dan sikap bertanggung jawab atas apa yang mereka kerjakan (Ruslan, Elly dan Aini: 2016). Mungkin hal itu terlihat sangat sederhana dan hanya sebatas tindakan kecil, namun akan sangat penting bagi kehidupan anak-anak nanti di usia remaja sebab mereka sudah terbiasa melakukan kebaikan dan sikap yang sesuai dengan aturan dan juga norma-norma yang berlaku sehingga akan menimbulkan keengganan ketika mereka akan melakukan pelanggaran moral. 
Banyak sekali cara-cara yang dapat di tempuh untuk dapat menanamkan nilai karakter dan moral pada remaja. mengutip dari (Abbas, 2019), mengatakan bahwa menurut beliau dalam jurnalnya, penanaman nilai moral dapat dilakukan melalui transfer nilai-nilai budaya lokal. Sama halnya dengan menggunakan kearifan lokal untuk mendidik murid-muridnya, namun penanaman nilai moral di sini lebih kepada mencontoh kepada seorang tokoh ulama banjarmasin yaitu KH. Abah Guru Sekumpul yang menjadi tauladan segala perilaku dan perbuatanya. Hal itu dapat di jadikan sebagai sebuah metode untuk mendidik siswa dengan menggunakan contoh-contoh dan juga ajaran yang di berikan oleh ulama besar itu untuk menanamkan nilai-nilai moral pada peserta didik di kelas. Jadi penanaman nilai moral tidak berpaku pada satu objek, namun banyak objek yang dapat di jadikan sebagai sebuah contoh untuk mentransfer nilai-nilai budaya yang menumbuhkan moral kepada anak.

\section{KESIMPULAN.}

Moral merupakan sebuah ukuran dari sikap dan perilaku seseorang, orang akan dikatakan bermoral apabila ia dalam berperilaku memiliki etika yang baik dan tidak melanggar norma yang berlaku di masyarakat. namun di masa sekarang ini, tidak sedikit generasi muda yang memiliki perilaku tidak bermoral dalam dirinya. Terjadinya kemerosotan moral pada generasi muda di era modern sekarang ini di pengaruhi oleh beberapa faktor, Satu diantaranya yaitu di karenakan oleh adanya faktor globalisasi yang membawa banyak pengaruh yang datang dari luar, baik itu berupa kebudayaan, kehidupan sosial dan juga teknologi.

Globaliasasi dapat menjadi hal yang positif apabila para generasi muda sekarang dapat mengambil hal-hal positif dari adanya globalisasi itu. Namun akan menjadi sebuah hal yang buruk apabila generasi muda tidak dapat menyaring hal-hal positif nya dan mengambil hal negatif dari apa yang ada pada globalisasi tersebut, yang tentunya akan mempengaruhi baik buruknya moral seseorang. Adapun cara yang dapat di lakukan untuk mengatasi permasalahan tersebut yakni dengan pendidikan, baik pendidikan secara non formal, maupun pendidikan secara formal. Dengan adanya pendidikan, tentunya moral seseorang akan diarahkan sesuai dengan norma dan aturan agar perilaku seseorsng tidak melewati batas, dan supaya seseorang memiliki perilaku yang baik dalam kehidupan sosialnya di masyarakat. 


\section{DAFTAR PUSTAKA}

Abbas, E. W. (2015). Pendidikan IPS berbasis Kearifan Lokal. WAHANA Jaya Abadi

Aini, N., \& Ruslan, R., \& Ely, R. (2016). Penanaman nilai-nilai moral pada siswa di sd negeri lampeuneurut. Jurnal Ilmiah Mahasiswa Pendidikan Guru Sekolah Dasar, $1(1)$.

Bahri, S. (2015). Implementasi Pendidikan Karakter Dalam Mengatasi Krisis Moral di Sekolah. Ta'alum, Vol 03, no 01

Fahrudin. (2014). Proses pendidikan nilai moral di Lingkungan Keluarga sebagai Upaya mengatasi Kenakalan Remaja. Jurnal Pendidikan Agama Islam- ta'lim. Vol 12 No 1.

Mutiani, M. (2018). Literasi Budaya Lokal Sebagai Wahana Edukasi di Era Milenial

Subiyakto, B., \& Abbas, E,W. (2020). Strategi Pembelajaran IPS:konsep dan aplikasi

Subiyakto, B.,\& Mutiani, M. (2019). Internalisasi nilai pendidikan melalui aktivitas masyarakat sebagai sumber belajar ilmu pengetahuan sosial. Khazanah: Jurnal Studi Islam dan Humaniora, 17(1), 137-166.

Susanto, H. (2015) Cross-Indigenious Pembelajaran IPS dalam mengajarkan Nilai-nilai Multikulturalisme melalui Pemahaman Kerarifan Lokal.

Syaharuddin, S., Pasani, C. F., \& Mariani, N. (2016). Implementasi Pendidikan Karakter Berbasis Kearifan Lokal Bakumpai di SDN Batik Kabupaten Barito Kuala. 